\title{
The Development of Gateball Basic Technique Training Model based on Adobe Flash Player (Development Studies at Gateball Club in Semarang City)
}

\author{
Fajar Arif Indrajaya; Sugiyanto; Agus Kristiyanto \\ Sport Science, Sebelas Maret University, Surakarta, Indonesia \\ http://dx.doi.org/10.18415/ijmmu.v6i5.1132
}

\begin{abstract}
Gateball's basic engineering training materials have varied variations, but the basic technique training model is minimal. This makes Gateball players difficult to understand the basic technique of training material the trainer is given. Therefore, it takes a new Gateball basic engineering exercise model to make it easier to understand. The main objective of this research is to produce a gateball base engineering training model based on Adobe Flash Player which can help coach, builder, and player in Semarang City. This type of research is the research and development that uses the model of development of the Borg and Gall. Based on the stage adaptation of the model of development of the Borg and Gall then obtained the following results. Assessment and validation of learning media expert with very good value of $69 \%$. Assessment and validation expert material shows excellent learning media with a value of 95\%. Assessment and validation of expert practitioners showed media categories include excellent value with $77.5 \%$. A small group of trial results showed considerable learning valid media value of $78.54 \%$. A large group of trial results demonstrate the value of valid learning media $80.27 \%$. On operational test shows that the media categories include very good with average 4.58. On test the effectiveness of products put in place pre test and post test against a control group and a treatment group. Test results showed that the effectiveness of learning media has a significant value of effectiveness of significance $(\mathrm{p}$ value $)<0.010 .05$ means that the media effectively. As a final summary stated that viable and proven effective product enhance the basic techniques of gateball sports on sports clubs gateball in Semarang city.
\end{abstract}

Keywords: Gateball; Training; Adobe Flash Player

\section{Introduction}

Gateball Sports began to be known by Indonesian people in 1994 through Japanese tourists who came to Bali. Through Bali, this sport also spread to various regions in Indonesia, one of which is Semarang city. Dated 20 May 2011 Gateball Association of Indonesia (PERGATSI) was established, with the father of Djoko Kirmanto as the first chairman of PERGATSI. During this time PERGATSI has joined a member of the Indonesian Community Recreation Sports Federation (FORMI), then the year 2013 was accepted to become a member of the National Sports Committee (KONI). [10]. In Gateball game there are elements inhibiting opponents or helping friends earn points, the order of beating 
according to the number of balls and each turn allowed only one player who is in the field, then each player must master the technique Basis to support the use of strategies [11].

Exercise is a systematic process of practicing repeatedly, with an increasing number of days to increase the amount of training weight and exercise intensified [4]. Exercise can also be defined as a systematic participation that aims to increase the physical functional capacity and endurance of the exercise. The exercises determine the emergence of changes in the network and system, changes relating to the development of ability to exercise [7].

The basic techniques in Gateball include stroke, touch punch, and Meteor Punch [9]. Gateball Basic Technique training material is very diverse, but the fundamental technique practice model is very minimal and conventional (on the pitch only), so players tend to be saturated and not easily understand basic technique training materials provided by the trainer. Appropriate learning media is required and helps in the training process.

The Media in teaching is indeed the most important role as a tool to create a teaching learning process [8]. Media is a tool and material used in the learning process tends to be interpreted as graphic, photographic, or electronic tools for capturing, processing, and rearranging visual or verbal information [1].

Adobe Flash Player is a software to create various forms of visual offerings that can be an input of various media, such as video, animation, images, and sound [5]. The results of Adobe Flash Player can also be displayed in various media such as websites, VCD, DVD, and Android-based mobile phones [3]. The use of interactive media with Adobe Flash Player in Gateball basic technique exercises made an alternative learning to overcome the constraints mentioned. The study aims to produce a Gateball basic engineering model-based Adobe Flash Player.

\section{Method}

The development model in the study was adapted from the Borg \& Gall Development Model (1983). The development Research measures Borg \& Gall are: (1) Research and information collection, (2) planning, (3) The development of product drafts, (4) Preliminary field trials, (5) Revise the results of the trial, (6) Field trials, (7) Refinement of field test products, (8) field implementation test, and (9) refinement of the final product, (10) dissemination and implementation. So these development studies procedurally should go through several stages that have been mentioned [2].

\section{Results and Discussion}

\section{A. Research and Information Collection}

After researchers carried out preliminary studies, researchers follow up with some notes from each of the Gateball Sports Club trainers in the city of Semarang. In essence, most gateball trainers have never used interactive media in the training process, so most players are still struggling to understand the basic techniques of good and true, and how to play them.

In the interview session, the trainers explained that there is difficulty developing the basic techniques of gateball sports exercises due to the limitation of reference, but the students are difficult to practice and understand the basic techniques Gateball Sports due to the lack of training media to facilitate 
or help students to practice and improve the basic techniques of gateball sports, so that in routine training process becomes less than maximal.

\section{B. Planning}

The planning phase consists of an assessment of supporting theories on the exercise media and basic technique exercises of gateball sports as well as initial draft drafting phase of the development product. Theoretical assessment is necessary to underlie the formulation of a product that in this case is the product of development of training Media basic technique Gateball Sports based Adobe Flash Player. The theories used are general knowledge theory of Handball sports and basic technique exercise theory, and the supporting aspects of exercise theory.

\section{The Development of Product Drafts}

After going through the process of design and production then produced the initial product of development of training Media basic technique Gateball Sports based Adobe Flash Player. In accordance with the steps in the exercise process then the initial product draft of the development of training Media basic technique Gateball Sports based Adobe Flash Player as follows:

(a) Gateball sports knowledge general materials.

(b) Pendulum Blow basic technique training material.

(c) Basic techniques of cone punch technique.

(d) A Sparking punch technique basic training material. (e) Student Profile, specialist, practitioner, Media expert, and mentor lecturer.

At the evaluation stage, the tool members used to acquire the data were using a mixed questionnaire consisting of a closed answer question (a predefined answer), and an open answer (direct answer from the speaker). The answers from scholars are noted by researchers in accordance with the principal answers issued by experts. The result of a review of the expert evaluation stage in the form of quantitative data is further processed using Likert scale and qualitative data for evaluation with input questions from the resource.

Evaluation Data obtained from 3 qualified experts: Academics experts, media experts and handball sports practitioners. The media experts in this development product are Dr. Hanik Liskustyowati, M. Kes. Which is the Faculty of Physical Education and Health University of eleven March. Experts in this development product are Drs. Tri Nurharsono, M. Pd. Who is a lecturer in physical Education and health Department of Semarang State University and is also the head of PERGATSI of Semarang. Researchers use expert practitioners aiming to enhance the quality of the developed products. Practitioners in this development product are Sugeng Priyono, S. H, M.Si. Which is the junior team trainer and the Gateball senior sports team of Semarang.

The overall Data gained from expert evaluation can be concluded that the product is valid and worthy to be tested at the effective stage of the product. Of course before applying, researchers previously noticed the inputs of the sports expert hand ball so that the product is better. In table 1 can be presented quantitative data from the results of the third evaluation of the handball expert: 
Tabel 1. Recapitulation of Expert Test Score Results

\begin{tabular}{|c|c|c|c|c|}
\hline No & Expert & $\begin{array}{l}\text { Result } \\
\text { Score }\end{array}$ & $\begin{array}{l}\text { Max } \\
\text { Score }\end{array}$ & Presentase \\
\hline 1. & $\begin{array}{l}\text { Media } \\
\text { Expert }\end{array}$ & 59 & 85 & $69 \%$ \\
\hline 2. & $\begin{array}{c}\text { Akademic } \\
\text { Expert }\end{array}$ & 76 & 80 & $95 \%$ \\
\hline 3. & $\begin{array}{c}\text { Practition } \\
\text { Expert }\end{array}$ & 62 & 80 & $77,5 \%$ \\
\hline \multicolumn{2}{|c|}{ Total } & 198 & 245 & $80,81 \%$ \\
\hline
\end{tabular}

In table 1, the results of the percentage of the final result are $80.81 \%$ and it can be interpreted that the design of the basic techniques of training media for Gateball based on Adobe Flash Player can be tested at a later stage. It is based on the classification of [6].

Tabel 2. Presentase of Evaluation Score [6]

\begin{tabular}{|l|c|}
\hline Presentase & Description \\
\hline $80 \%-100 \%$ & Valid \\
\hline $60 \%-79 \%$ & Valid Enough \\
\hline $50 \%-59 \%$ & Less Valid \\
\hline$<50 \%$ & Not Valid \\
\hline
\end{tabular}

The results of analysis conducted by researchers in the form of qualitative and quantitative data. From these two data can be concluded that the design of products that have been designed can continue to be discovered next.

\section{Preliminary Field Trials}

At this stage, researchers use the subject of players from the pen club and the Pandavas that amounted to 8 players. The implementation of small group trials is on the third week of June 2019 at the Balai Besar District Sungai Pemali Juana Semarang. The implementation of small group tests initiated researchers from explaining the mechanisms in the explanation of activity objectives and the charging of polls.

Tabel 3. Quantitative Data Preliminary Trial Results

\begin{tabular}{|l|l|l|l|l|}
\hline No & \multicolumn{1}{|c|}{ Aspect } & $\begin{array}{l}\left(\sum\right. \\
\mathrm{X}) \\
\mathrm{N}=8\end{array}$ & $\left(\sum \mathrm{Xi}\right)$ & $(\%)$ \\
\hline 1 & Understandable & 94 & 120 & $78,33 \%$ \\
\hline 2 & Easy to Do & 94 & 120 & $78,33 \%$ \\
\hline 3 & Interesting & 96 & 120 & $80 \%$ \\
\hline 4 & Benefits & 93 & 120 & $77,5 \%$ \\
\hline \multicolumn{2}{|c|}{ Average } & & & $78,54 \%$ \\
\hline
\end{tabular}

Description :

$\mathrm{N} \quad$ : Total Subject

$\left(\sum X\right)$ : Score Result

$\left(\sum X \mathrm{X}\right)$ : Max Score

(\%) : Presentase 
In table 3 can be explained that the results of a small group test on this development research can be categorized as valid and usable. Of course, it refers to the criteria used by researchers. So the conclusion that has been done at this stage is based on a theory and valid data. After the researchers get the data and input from the subject and the trainer, the researcher performs a revision of the product that has been designed.

\section{E. Revision of Trial Results}

Recommendations from the media experts mentioned that background music selection should be more spirited, then the recommendation of a writing scholar scholars should be sequential and clear, and for practitioners requesting that the video is provided repetition and throttling so that The training model learning process becomes easier. The recommendation from these experts was made a reference for product repair materials at the time of the field trials.

\section{F. Final Field Test}

The evaluation made from the previous test result is used as a reference material for the next stage. The implementation of this stage was held in June 2019 at the Balai Besar of Pemali Juana, Semarang. The number of subjects used in this stage is 12 Gateball club players in the city of Semarang taken from the clubs Pena, Pandawa, and Lawang Sewu. As with the small group Test stage, the researcher gave an explanation to the subject about the charging questionnaire.

Tabel 4. Quantitative Data final Test result

\begin{tabular}{|l|l|l|l|c|}
\hline No & \multicolumn{1}{|c|}{ Aspect } & $\begin{array}{l}\left(\sum\right. \\
\mathrm{X}) \\
\mathrm{N}=12\end{array}$ & $\left(\sum \mathrm{Xi}\right)$ & $(\%)$ \\
\hline 1 & Understandable & 140 & 180 & $77,77 \%$ \\
\hline 2 & Easy to do & 141 & 180 & $78,33 \%$ \\
\hline 3 & Interesting & 141 & 180 & $78,33 \%$ \\
\hline 4 & Benefits & 156 & 180 & $86,66 \%$ \\
\hline & & & & \\
\hline
\end{tabular}

Description :

$\mathrm{N} \quad$ : Total Subject

$\left(\sum X\right)$ : Score Result

$\left(\sum \mathrm{X} i\right)$ : Max Score

(\%) : Presentase

The percentage obtained indicates that the test results in the category are valid and usable. However, in this stage researchers also gained input from the subject and the trainer. The results of data and inputs are accommodated by the study before performing the test stage of product effectiveness so that the product is expected to actually be able to do and understood by the subject.

\section{G. Improvement of Field Test Products}

The result of the response from the subject after the extensive trial implementation can be concluded that the design of the product compiled by the researcher can be accepted and continue to be able to test the effectiveness. The conclusion was obtained from the overall stages of evaluation and analysis conducted by researchers. In addition, feedback from experts is the data that supports the conclusion of the product design. 


\section{H. Test Field Implementation}

The field implementation test is conducted to assess the quality of learning media products and the effectiveness of products by gateball players. Operational tests involve 10 Gateball players to assess product quality and test product effectiveness, as well as 10 Gateball club players as a control group for product effectiveness testing.

Tabel 5. operational Test Results

\begin{tabular}{|c|l|c|c|c|l|}
\hline \multirow{2}{*}{ Responden } & \multicolumn{3}{|c|}{ Rerata skor Aspek } & Rer & Kriteria \\
\cline { 2 - 4 } & Tampilan & Isi & belajar & ata & \\
\hline 1 & 4,66 & 4,66 & 4,00 & 4,44 & Sangat baik \\
\hline 2 & 4,33 & 4,66 & 4,33 & 4,44 & Sangat baik \\
\hline 3 & 4,00 & 4,00 & 5,00 & 4,33 & Sangat baik \\
\hline 4 & 5,00 & 4,00 & 5,00 & 4,66 & Sangat baik \\
\hline 5 & 4,33 & 4,66 & 5,00 & 4,66 & Sangat baik \\
\hline 6 & 4,00 & 4,66 & 4,66 & 4,44 & Sangat baik \\
\hline 7 & 5,00 & 5,00 & 5,00 & 5,00 & Sangat baik \\
\hline 8 & 5,00 & 4,66 & 5,00 & 4,88 & Sangat baik \\
\hline 9 & 4,66 & 5,00 & 4,33 & 4,66 & Sangat baik \\
\hline 10 & 4,00 & 4,33 & 4,66 & 4,33 & Sangat baik \\
\hline Rerata & 4,49 & 4,56 & 4,69 & 4,58 & Sangat baik \\
\hline
\end{tabular}

Based on the results of operational trials with the subject of 10 players Gateball club in Semarang City to three aspects of assessment, namely the aspect of display, aspects of content or material, and aspects of learning can be concluded that the media including the criteria "very good" with Average score 4.58 .

The effectiveness test in this development product aims to see the difference in influence capability of performing the basic technique of gateball sports techniques from development results using interactive media with groups using only Practice conventionally. The conventional exercise in question is the practice by how coaches demonstrate basic techniques of gateball sports balls directly in front of the players.

Tabel 6. Product Effectiveness Test Results

\begin{tabular}{|l|l|l|}
\hline Data & Teknik Dasar & Signifikansi $(\boldsymbol{p})$ \\
\hline $\begin{array}{l}\text { Keefektifan Media } \\
\text { Pembelajaran Interaktif dengan } \\
\text { Makalah }\end{array}$ & Kerucut & 0,008 \\
\cline { 2 - 3 } & Pendulum & 0,022 \\
\cline { 2 - 3 } & Sparking & 0,001 \\
\hline Rerata & $\mathbf{0 , 0 1}$ \\
\hline
\end{tabular}

Because the value of significance ( $\mathrm{p}$ value) of the basic Technique (0.01) is smaller than 0.05 then there are significant gateball basic engineering skill scores in the group of players given interactive learning media and the players given the paper. 


\section{Completion of Final Product}

After the implementation of the test, the revision of the test results carried out as a repair of the product that has been tested based on responses and feedback from the subjects. Revision results indicate that the product of the training media development is worth using.

Products from the development of the Gateball basic technique exercise model can be seen in the following screenshot:

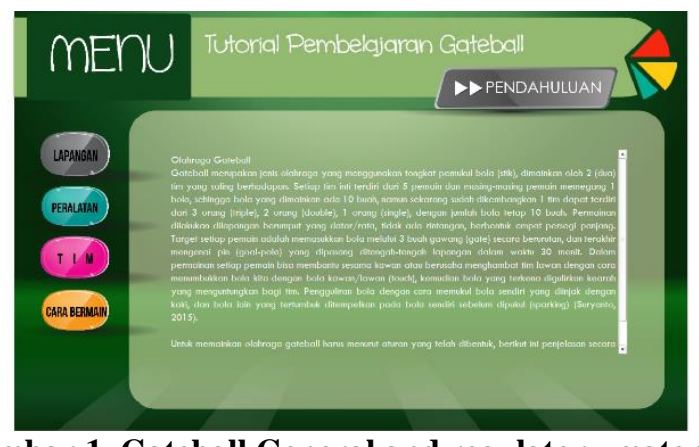

Gambar 1. Gateball General and regulatory materials

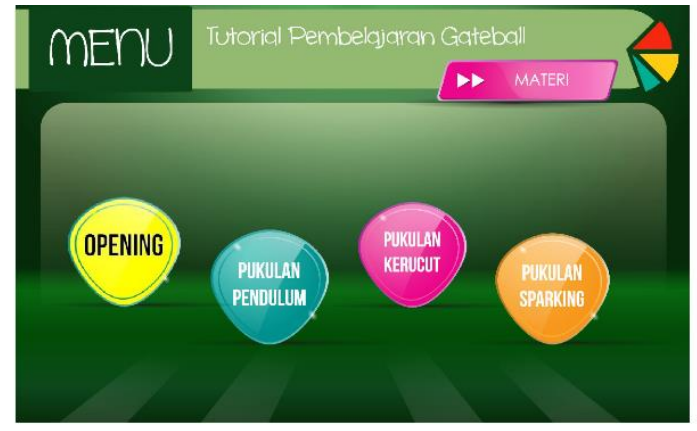

Gambar 2. Gateball Basic Technique Training Material

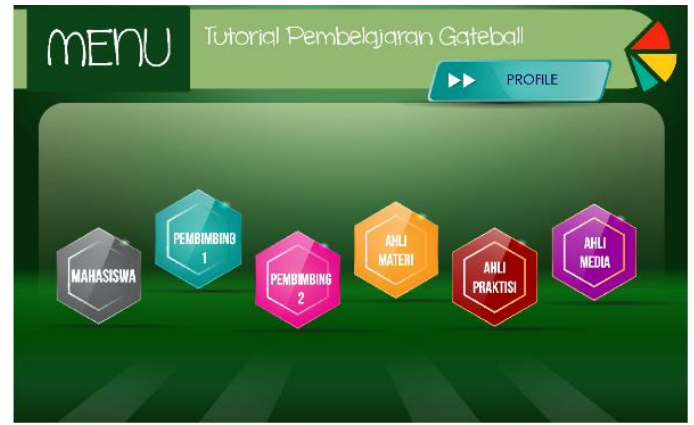

Gambar 3. Student profile, mentor Lecturer, and Gateball expert

\section{J. Diseminasi dan Implementation}

Researchers have been dissemination of this product at a national seminar twice, namely in Surabaya, and Banyuwangi. The author has also implemented this product on all Gateball clubs in the city of Semarang. 


\section{Conclusion}

The process of development of training Media basic technique Gateball Sports based on Adobe Flash Player in the city of Semarang has been through several stages. The stages of learning multimedia development that has been traversed from the introduction stage, learning design development, production, and product evaluation ultimately resulted in the final product of multimedia learning techniques training base Gateball Sports for club players in the city of Semarang.

The result of expert assessment of the quality of multimedia learning Media Training Basic Technique Gateball Sports based Adobe Flash Player in Semarang City is included in "excellent" criteria, the final data of the percentage is $80.81 \%$ and can be It is interpreted that the product design of the basic engineering exercises of the Gateball-based sport of Adobe Flash Player can be tested at a later stage.

Small group test results for the valuation component which contains the aspect of conformity, benefits, safety, and implementation aspects gained $78.54 \%$ of the total for the product's feasibility conclusions.Large group test results for the valuation component which contains the aspect of conformity, benefits,safety, and implementation aspects gained $80.27 \%$ of the total for the product's feasibility conclusions. Based on the criteria set it can be concluded that the basic technique of training media of Gateball based on Adobe Flash Player is valid and can be used as the result of data within the range of 80 - $100 \%$ for percentage classification Product eligibility. Operational test results that contain aspects of appearance, content, and learning are obtained average 4.58 that are in the category very good.

The test results of the effectiveness of this exercise media final product is effective, because the value of significance ( $p$ value) of Gateball basic Technique (0.01) is smaller than 0.05 , which means that there is a significant Gateball basic engineering skill score in the group of players Which is given interactive learning media and the player given the paper.

Product of research and development of Gateball basic engineering exercises based on Adobe Flash Player are declared worthy, valid, and effective.

\section{References}

[1] Arsyad, Azhar. (2004). Media pembelajaran. Jakarta : Raya Grafika Persada.

[2] Borg, W. R. \& Gall, M.D. (1983). Educational research an introduction (4^th ed.). New York: Longman.

[3] Deni Darmawan. 2012. "Pendidikan.Teknologi Informasi dan Komunikasi". Bandung: P.T Remaja Rosda Karya.

[4] Harsono. 1988. "Coaching and Aspek-aspek Psikologi dalam Coaching". Bandung: C.V Tambak Kusuma.

[5] Madkoms. (2012). Kupas tuntas adobe flash professional cs6. Yogyakarta: ANDI.

[6] Maksum, A. (2009). Buku Ajar Mata Kuliah Metodologi Penelitian Dalam Olahraga. Surabaya: FIK UNESA.

[7] Pate, et al. 1993. "Dasar-dasar Ilmiah Kepelatihan Dasar". Semarang. IKIP Semarang Press. 
[8] Sudjana, Nana. 1989. "Dasar-dasar Proses Belajar Mengajar. Bandung: Sinar Baru.

[9] Suryanto. (2015). Bermain Gateball. Jakarta.

[10] World Gateball Union. What's Gateball. 2015.

[11] World Gateball Union. World Gateball Rules. 2015.

\section{Copyrights}

Copyright for this article is retained by the author(s), with first publication rights granted to the journal.

This is an open-access article distributed under the terms and conditions of the Creative Commons Attribution license (http://creativecommons.org/licenses/by/4.0/). 